\title{
KNOWLEDGE AND INFORMATION MANAGEMENT
}

doi: 10.2478/czoto-2021-0001

Date of submission of the article to the Editor: 12/12/2020

Date of acceptance of the article by the Editor: 24/03/2021

Piotr Kuryło ${ }^{1}$ - orcid id: 0000-0001-9820-1254

Adam Wysoczański ${ }^{2}$

Piotr Bonarski ${ }^{3}$

1 University of Zielona Gora, Faculty of Mechanical Engineering, Department of Mechanical Engineering and Safety, Poland

${ }^{2}$ University of Zielona Gora, Faculty of Mechanical Engineering, Department of Mechanical Engineering and Safety) and Technonicol-Insulation, Poland

${ }^{3}$ Technonicol-Insulation, Poland

\section{Abstract:}

The paper describes selected issues related to knowledge management in a manufacturing company with a detailed analysis of the impact of optimal management using the MES system on financial and production results. The study presents an analysis of the company's results before and after the implementation of the knowledge and information management system in a manufacturing company. Moreover, the paper presents an analysis of the company's operations and defines a strategy for further activities aimed at increasing the financial and operational efficiency of the analysed production company.

Keywords: Failure management, Reengineering, Manufacturing Execution System (MES), Overall Equipment Effectiveness (OEE)

1. INTRODUCTION Knowledge management is a process that allows the use, creation and dissemination of knowledge for tasks related to the implementation of organizational goals. During the introduction of IT systems, the analysis of "dry" data and information was started, which allowed facilitating and improving the effectiveness of decision-making processes in companies. The next step in the development of enterprises was the introduction of an additional level, which increased the efficiency of information management - knowledge (Biznes, 2007; Szabó and Csepregi, 2011).

The main assumptions of increasing the efficiency of information management were the use of employees' knowledge contained in their minds resulting from their talents and professional experience acquired during many years of work in the enterprise - it was the so-called hidden knowledge. On the other hand, information that could become a source of knowledge for new employees employed in the organization was prepared in the form of, for example, descriptions, solutions to unusual problems, notes from meetings - it was open knowledge. 
Companies after introducing such solutions as TQM (Total Quality Management), downsizing (Polish: Reducing the size of any element), reengineering (Polish: reconstruction), benchmarking (Polish: comparative research or comparative analysis) began looking for solutions that will provide an impulse to increase their position among competitors.

The basic problem that emerged with the classical approach to knowledge management was the difficulty in objectively viewing the accounting for intangible resources of the enterprise and presenting them in the balance sheet. The conditions changed radically at the turn of $2011 \div 2013$ with the emergence of a new area of financial accounting: accounting of competency assets and intellectual capital.

There was then a shift in the perspective of theory related to accounting towards intangible resources of the company and it became possible to create formal economic information bases for managing this resource (Grudzewski and Hejduk, 2018; Niemczyk, 2013).

Organizations are currently struggling with the problem of the optimal use of previously gained employee experience in a wider scope. Problems and dilemmas that arise during design and production should be properly recorded and archived to avoid complex analyses when problems reoccur. The answer to the above question appeared also thanks to the development of modern information and communication technologies, which in most cases became the main pillar in knowledge management. Companies involved in the design and programming of computer applications present solutions based on creating databases that allow archiving the acquired knowledge and information in such a way that other people can remotely connect to the database and use the collected resources. The benefits that can be achieved using the knowledge and information management methodology relate to three entities: employees, enterprises and the market.

At the enterprise level, the following benefits can be defined: increase in creativity, enterprise development, reduction of management costs, increase in management effects. Referring to employees, the obtained benefits are: self-fulfilment, selfdevelopment, increase in competences and performance, increasing the employee's competitiveness on the labour market. Benefits defined in relation to the market are: understanding customer needs, information exchange, ideas for new services and products. This applies to both business partners and competitors. The result of the implementation of the proposed solutions is the creation of an effective management system, which consists of a new company culture and strategy, the pillar of which is primarily knowledge (Brillman, 2002; Kisielnicki, 2004).

Three models should be used in a knowledge management system (Stabryła, 2012):

1. Japanese model. This model is based on tacit and formal knowledge and the authors of this model are: I. Nonaka and H. Takeuchi.

2. Stock Model. The creator of this model is D. Leonard Barton. He argued that for the efficient functioning of the system, there should be a relationship between five elements: employee knowledge and skills, management system, experimenting, using new technology, joint solution.

3. Process Model. This model is based on studies and practical experience. In this assumption, three key elements of knowledge management are distinguished: knowledge creation process, knowledge codification process, knowledge transfer process. The authors of the model are: T.H. Davenport and L. Prusak. 


\section{SELECTED ISSUES RELATED TO KNOWLEDGE MANAGEMENT}

Selected issues related to knowledge management in manufacturing companies, such as TQM and downsizing, are presented and explained below.

TQM (Comprehensive Quality Management) appeared at the turn of the 1970s and 1980s in the United States and began to be "fashionable", but the origins of TQM should be sought already in the 1920s in Walter Shewhart's research on the static description of variability in production. TQM is a type of quality management ideology based on continuous improvement and evaluation of all elements of the organization. All employees are involved in this process through teamwork, commitment and constant improvement of professional qualifications. The aim of the presented activities is to achieve long-term success, the source of which is customer satisfaction, benefits for the organization and society. The pillars of comprehensive quality management are presented below (Glosariusz, 149; Matusiak, 2011).

\section{Pillar I}

Commitment of all employees of the company to the improvement of the smallest aspects of the business.

\section{Pillar II}

Process optimization. The use of understandable and universal machines and tools that can be easily and quickly changed, thus maximizing the availability time for production.

\section{Pillar III}

The main aspect of most quality problems is inadequate company management, motivation. Only a few percent of errors are caused directly by employees at the production machine.

\section{Pillar IV}

Achieving success through the use of TQM is delayed in time, because only the long-term use of the methodology will bring an advantage over the competition.

Downsizing is another popularly used tool. It consists in reducing the weight (importance) or quantity of products in the package, or optimizing the more expensive ingredients in the product or device while maintaining the same price. A good example of the use of downsizing methods is in the automotive sector. It consists in replacing large (heavy) elements with others of smaller weight or capacity while maintaining the same parameters thanks to components such as compressors or turbochargers. The advantages of using the described method are lower mass of the produced element, lower emission of pollutants and high torque available from moderate revolutions and economic performance characteristics. In practice, however, opinions on the application of the described method in engines differ, because these engines were characterized by high exhaust emission and low service life, which also led to a partial retreat from this path in the production of drive units in the mid-2010s on the basis of the data about falsifying combustion reports.

\section{KNOWLEDGE MANAGEMENT IN MAINTENANCE DEPARTMENTS BY APPLICATION OF APPROPRIATE SYSTEMS}

The main elements that define the production capabilities of enterprises is the availability and reliability of the machine park. The indicators that allow determining and monitoring the current condition, technical condition of the machine park and the effectiveness of the operation of technical departments are MTTR, MTBF, MTTF (Bodył, 2016; Wojtkowiak): 
MTTR (Mean Time To Repair) - average repair time from the moment of failure to repair of the damaged device. On the basis of this indicator, the effectiveness of technical services can be determined. If the average time of failure removal is high, it may mean that employees of technical departments do not have sufficient competences, available tools or spare parts needed for efficient failure removal. If the MTTR indicator exceeds the assumed value, the root cause of the problem should be identified immediately and corrective actions implemented.

MTBF (Mean Time Between Failures) - the average time between failures (uptime) using the above indicator, it is possible to plan preventive actions for specific parts in the machine. According to the rule, it should be assumed that preventive replacement of parts occurs every $85 \%$ of MTBF, it is obviously a rule that is only a standard determinant, while each company should define its standard adapted to the specificity of production and machines. This indicator allows defining the effectiveness of the performed preventive actions. If it is at a high level, it means that the TPM activities carried out bring the expected results. However, if it is at a low level, the inspection plan and the conscientiousness of their implementation should be verified.

MTTF (Mean Time To Failure) - the average time to failure is defined on the basis of the device operation time from the beginning of its operation or from the last repair to the first failure.

The three most important indicators above should be monitored in the maintenance department in order to correctly define the actions taken and determine their effectiveness. At this point, the question arises: how to raise the knowledge of technicians and engineers so that they can fully carry out their tasks?

Apart from specialized training and exchange of experiences, an important element that will allow the achievement of indicators at the desired level is knowledge management in the organization. In today's world, staff shortages and high employee turnover are a major problem. A good solution to the problem presented above is to create a database that will describe the course of the failure along with the results of the carried out work. During the failure, the employee operating the machine enters this information into the supervisory system (e.g. in the CMMS system presented below), at the same time the technical department receives information (it appears on the computer or telephone) about the problem, along with the defined place and time of occurrence. This allows for a quick reaction and start of work. After the operation is completed, the maintenance worker is obliged to "close" the failure in the system by specifying the time of ending the failure and a description of actions taken during the repair. This allows the management to monitor the status of technical staff activities on an ongoing basis, monitor indicators (they are calculated automatically on the basis of entered information) and create a database of failures (Horodecki, 2016; Glosariusz, 86).

Anyone who has access to the described database of failures and in the event of a similar problem in the future will be able to search for it by entering keywords and familiarize themselves with the procedures applied to remove the failure. Thus, there will be a real possibility of reducing the machine repair time and increasing the production capacity. It will also be possible to use "go-pro" cameras, which will allow visualizing the actions taken and saving them on the company's server. In addition to the full description of the steps taken, the technician will also be able to see the video of the previous event. This is additional information for the technicians, which will allow 
them to improve their competences and eliminate the failure in the shortest possible time (Mączyński, W., 2011; Marchwiński et al., 2010).

The next step that allows enterprises to improve their production capacity is the use of the TPM (Total Productive Maintenance) method. It is a method originating in Japan, which allows ensuring maximum efficiency of machines and devices. TPM should be divided into two levels:

I - Performed by the operator and II - performed by technical services. This method is based on planned machine stops in order to perform inspections, which will allow for failure-free operation until the next inspection. An important element in the application of this tool is the training of operators from the correct performance of the inspection activities contained in the inspection plan, which is prepared on the basis of the operation and maintenance documentation. It is well-known that an experienced operator who has knowledge and extensive experience in the operation and operation of a particular machine is not always available, so the question arises, how to quickly and effectively perform a particular activity?

When creating inspection plans, the person responsible for carrying out such inspection should prepare a detailed plan based on the technical documentation provided by the manufacturer and the gained experience. The next step should be the performance of all activities by the person who creates the instructions using a camera mounted to the helmet in such a way that all activities performed by the Engineer are clearly visible and understandable to all people watching the recorded video.

After completing the described activities, a detailed description of the performed task should be prepared and a film attached to it. Fully prepared documentation with a video should be an integral part of on-the-job training for the employee operating the machine and the technical staff who perform the inspections. Documentation should also be hosted on a server that can be easily found by the employees at any time during their work they could read the inspection instructions and the instructional video (Misiurek, 2017; Seiichi, 1988).

Such a database allows us to correctly manage knowledge in the enterprise, which translates directly into the improvement of production results by reducing downtime of machines and devices, and ultimately has a measurable impact on the financial result (Misiurek, 2015).

\section{APPLICATION OF MES SYSTEMS BASED ON amiMES}

MES systems (Manufacturing Execution System) (Fig. 1) is a system of information and communication of production areas. The described systems, using software, IT technologies and automation elements, allow for effective data collection (Fig. 2) in real time, directly from production machines along with their transfer to the business area. With the help of the MES system functionality, it is possible to get an immediate feedback signal about the current production performances in order to react appropriately and make efficient decisions (Graham, 1996; Willmott and McCarthy, 2001).

The information obtained from the system allows for a detailed analysis of key indicators (KPI) for production, such as e.g. MTTR, MTBF, MTTF and obtaining the current picture and using the full production capacity. The view of the data obtained and presented by the MES system supports the decision-making processes of the management and helps in achieving the appropriate results. 

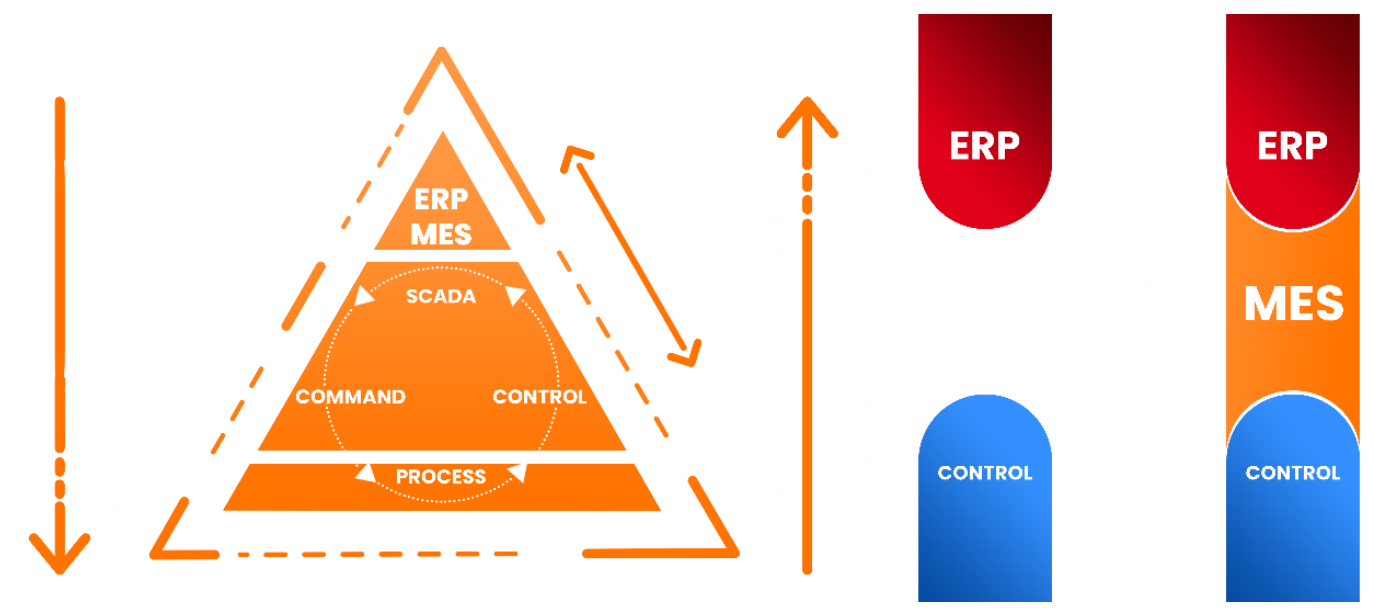

Fig. 1. The principle of operation of the amiMES system (www.amister.pl)

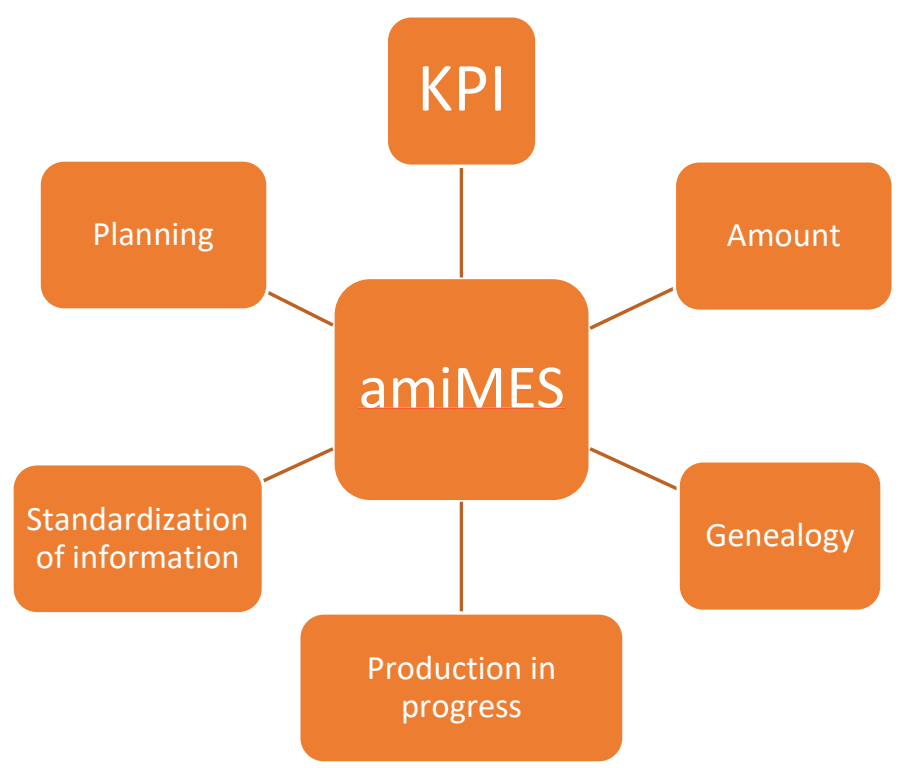

Fig. 2. Concentration points of the amiMES system (www.amister.pl)

\section{BENEFITS FROM THE APPLICATION OF KNOWLEDGE AND INFORMATION MANAGEMENT SYSTEMS IN AN ENTERPRISE BASED ON amiMES}

The advantages of using the above-described production support systems are the adaptation of information with the means of its transmission to selected groups of recipients, layered data acquisition, flexible approach to system design, because it is the user who decides what data should be monitored (determining the validity of the presented information), mobile access to real-time data via the cloud or VPN. The key element in the presented process is inference that accelerates the decision-making by the user, which enables a simplified access to information (Hamrol, 2015).

The process that enables a quick response to problems arising on the production line is the ability to monitor the parameters of production processes in real time. The user analyses the data presented in an appropriate manner and on their basis can take appropriate steps to protect the production against quality defects or permanent damage to production machines and devices (Fig. 3; Fig. 4) (www.amister.pl). 


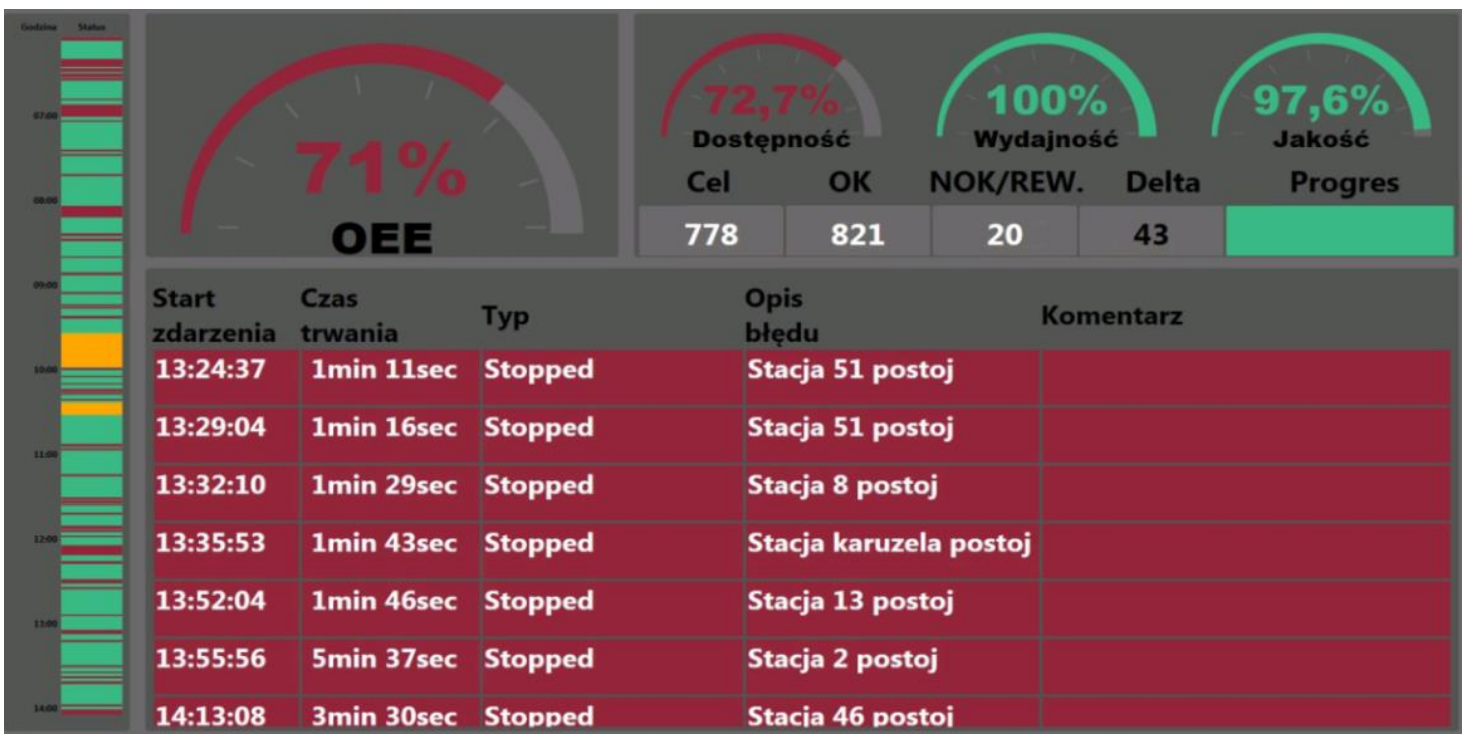

Fig. 3. Production indicators presented in real time (www.amister.pl)

Rekord: $1 / 2$

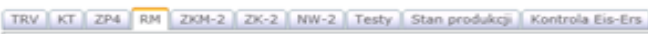

\begin{tabular}{|c|c|c|c|c|c|}
\hline \multicolumn{2}{|c|}{$\begin{array}{l}\text { Numer RM: } \\
\text { Not }\end{array}$} & 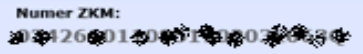 & $\begin{array}{l}\text { Poccatek produkcj: } \\
\text { 2011-11-02 08:25:38 }\end{array}$ & $\begin{array}{l}\text { Status: } \\
\text { IO }\end{array}$ & Lecktest: \\
\hline Typ: & Paleta: & Producent: & Koniec produkcji: & Poprawki: & wymiany: \\
\hline 0093 & 0031 & 2011 & 2011-11-02 09:45:02 & o & o \\
\hline
\end{tabular}

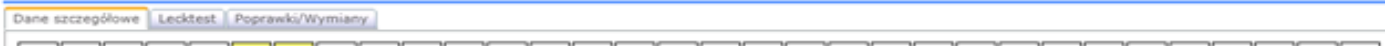

\begin{tabular}{|c|c|c|c|c|c|c|c|c|c|c|c|c|c|c|c|c|c|c|c|c|c|c|c|c|c|c|c|c|c|c|c|}
\hline o & $\begin{array}{c}2 \\
1 \\
10\end{array}$ & $\begin{array}{l}2 \\
1 \\
\text { I0 }\end{array}$ & i & ${ }_{0}^{s}$ & $\begin{array}{c}\mathbf{i} \\
\text { IOS }\end{array}$ & $\begin{array}{c}\text { i } \\
\text { I0- }\end{array}$ & $\begin{array}{c}8 \\
3 \\
10\end{array}$ & $\begin{array}{l}\mathbf{1} \\
\text { Io }\end{array}$ & $\begin{array}{c}10 \\
2 \\
10\end{array}$ & \begin{tabular}{|l} 
ut \\
1 \\
Io
\end{tabular} & $\begin{array}{l}{ }_{0}^{12} \\
0\end{array}$ & $\begin{array}{l}3 \\
0\end{array}$ & $\begin{array}{l}\text { 14 } \\
1 \\
\text { Io }\end{array}$ & \begin{tabular}{|c|}
55 \\
3 \\
10 \\
10
\end{tabular} & $\begin{array}{c}36 \\
1 \\
10\end{array}$ & $\begin{array}{c}y \\
2 \\
10 \\
10\end{array}$ & $\begin{array}{c}4 \\
1 \\
10 \\
10\end{array}$ & $\begin{array}{l}3 \\
1 \\
\text { Io }\end{array}$ & $\begin{array}{l}20 \\
0\end{array}$ & $\begin{array}{c}2 \\
1 \\
10\end{array}$ & $\mid$\begin{tabular}{|c|}
22 \\
1 \\
10 \\
10
\end{tabular} & \begin{tabular}{|c|}
23 \\
1 \\
10
\end{tabular} & $\begin{array}{c}24 \\
1 \\
10\end{array}$ & $\begin{array}{l}3 \mathrm{~s} \\
\text { o }\end{array}$ & $\underset{0}{a b}$ & $\begin{array}{l}20 \\
0\end{array}$ & as & $\begin{array}{c}3 \\
1 \\
10\end{array}$ & \begin{tabular}{|c|}
10 \\
1 \\
10
\end{tabular} & $\begin{array}{c}\mathrm{H} \\
1 \\
\mathrm{I} \\
\mathrm{I}\end{array}$ & $\begin{array}{c}n \\
1 \\
10 \\
\text { Io }\end{array}$ \\
\hline $\begin{array}{l}y \\
1 \\
10\end{array}$ & $\begin{array}{c}34 \\
2 \\
10\end{array}$ & \begin{tabular}{|c|}
3 \\
2 \\
10
\end{tabular} & $\begin{array}{l}36 \\
0\end{array}$ & $\begin{array}{l}{ }_{0}^{\prime} \\
0\end{array}$ & $\begin{array}{l}7 \\
14 \\
10\end{array}$ & $\begin{array}{c}38 \\
1 \\
10\end{array}$ & $\begin{array}{c}40 \\
1 \\
10\end{array}$ & $\begin{array}{c}41 \\
1 \\
10\end{array}$ & $\begin{array}{c}2 \\
2 \\
10\end{array}$ & \begin{tabular}{|c|}
4 \\
2 \\
10 \\
10
\end{tabular} & $\begin{array}{l}4 \\
4 \\
10\end{array}$ & $\begin{array}{c}5 \\
1 \\
10\end{array}$ & $\begin{array}{l}45 \\
10\end{array}$ & $\begin{array}{l}\text { I } \\
\text { Io }\end{array}$ & $\begin{array}{l}48 \\
7 \\
10\end{array}$ & $\ddot{\circ}$ & $\begin{array}{c}50 \\
2 \\
10\end{array}$ & $\begin{array}{c}51 \\
\mathbf{1} \\
1\end{array}$ & $\begin{array}{c}52 \\
1 \\
10\end{array}$ & $\begin{array}{c}5 \\
2 \\
10\end{array}$ & \begin{tabular}{|c|}
54 \\
15 \\
IOE
\end{tabular} & $\begin{array}{c}55 \\
1 \\
10\end{array}$ & $\begin{array}{c}56 \\
1 \\
10\end{array}$ & S & \begin{tabular}{|c|}
$\begin{array}{c}5 \\
3 \\
\text { IOS }\end{array}$ \\
\end{tabular} & \begin{tabular}{|c|}
59 \\
2 \\
105
\end{tabular} & $\begin{array}{c}6 \\
1 \\
10\end{array}$ & $\begin{array}{l}{ }_{161}^{61} \\
0\end{array}$ & ${ }_{0}^{2}$ & 8 & $\begin{array}{c}4 \\
1 \\
10\end{array}$ \\
\hline $\begin{array}{c}\text { s5 } \\
2 \\
10\end{array}$ & " & $\begin{array}{c}8 \\
1 \\
10\end{array}$ & $\begin{array}{l}\text { a } \\
1 \\
\text { Io }\end{array}$ & $\begin{array}{c}6 \\
3 \\
10\end{array}$ & $\begin{array}{c}70 \\
1 \\
10\end{array}$ & $\begin{array}{l}\text { r } \\
0\end{array}$ & $\begin{array}{c}72 \\
2 \\
10\end{array}$ & $\begin{array}{l}n \\
0\end{array}$ & $\begin{array}{c}74 \\
2 \\
10\end{array}$ & \begin{tabular}{|c|} 
is \\
IS \\
IOE
\end{tabular} & $\begin{array}{c}* \\
1 \\
\text { Io }\end{array}$ & $\pi_{0}^{\pi}$ & $\begin{array}{l}\pi \\
0\end{array}$ & $\overrightarrow{0}$ & $\begin{array}{c}60 \\
1 \\
10\end{array}$ & $\begin{array}{l}61 \\
0\end{array}$ & ह2 & $\begin{array}{c}51 \\
7 \\
10\end{array}$ & o4 & \begin{tabular}{|c|}
5 \\
1 \\
10
\end{tabular} & \begin{tabular}{|c|}
5 \\
2 \\
10
\end{tabular} & 7 & $\begin{array}{c}3 \\
7 \\
10\end{array}$ & : & \begin{tabular}{|c|}
0 \\
1 \\
1
\end{tabular} & \begin{tabular}{|c|}
$n$ \\
1 \\
Io
\end{tabular} & \begin{tabular}{|c|}
52 \\
1 \\
10
\end{tabular} & \begin{tabular}{|c|}
2 \\
1 \\
I0
\end{tabular} & $\begin{array}{c}34 \\
1 \\
10\end{array}$ & $\begin{array}{l}5 \\
\text { s }\end{array}$ & $\stackrel{*}{*}$ \\
\hline v & \begin{tabular}{|c|}
$n$ \\
15 \\
IOE
\end{tabular} & $\begin{array}{l}n \\
15 \\
\text { IOE }\end{array}$ & $\begin{array}{l}100 \\
0\end{array}$ & $\begin{array}{l}892 \\
15\end{array}$ & $\begin{array}{c}392 \\
2 \\
10 \\
10\end{array}$ & $\begin{array}{l}100 \\
15 \\
\text { IOE }\end{array}$ & $\begin{array}{l}100 \\
0 \\
0\end{array}$ & $\begin{array}{l}505 \\
15\end{array}$ & $\begin{array}{l}135 \\
15 \\
\text { IOE }\end{array}$ & \begin{tabular}{|l|}
15 \\
15 \\
IOE
\end{tabular} & $\begin{array}{l}1000 \\
1\end{array}$ & 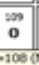 & $\begin{array}{c}120 \\
0\end{array}$ & ${ }_{0}^{114}$ & $\underset{0}{142}$ & $\begin{array}{c}113 \\
0\end{array}$ & $\begin{array}{c}124 \\
0\end{array}$ & $\begin{array}{c}\text { uss } \\
\mathbf{0}\end{array}$ & $\begin{array}{l}106 \\
0\end{array}$ & $\begin{array}{l}317 \\
0\end{array}$ & $\begin{array}{c}18 \\
0\end{array}$ & $\begin{array}{l}1198 \\
0\end{array}$ & $=0$ & $\begin{array}{c}221 \\
0\end{array}$ & ${ }_{0}^{122}$ & בx & 28 & $\begin{array}{c}125 \\
0\end{array}$ & ax & $\begin{array}{l}217 \\
\mathbf{0}\end{array}$ & 2at \\
\hline
\end{tabular}

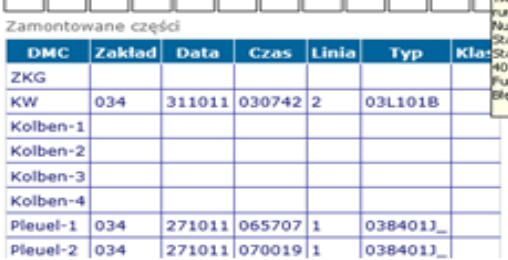

Rekord: $1 / 1 \quad<\rightarrow$

\begin{tabular}{|l|l|l|l|l|l|l|l||l|l|}
\hline TRV & KT & ZP4 & RM & ZKM-2 & ZK-2 & NW-2 & Testy & Stan produkcji & Kontrola Eis-Ers \\
\hline
\end{tabular}

\begin{tabular}{|c|c|c|c|c|c|}
\hline \multicolumn{2}{|c|}{ 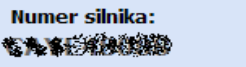 } & 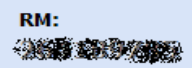 & $\begin{array}{l}\text { Początek produkcji: } \\
\text { 2011-06-30 20:01:02 }\end{array}$ & $\begin{array}{l}\text { Status: } \\
\text { IO }\end{array}$ & $\begin{array}{l}\text { Lecktest: } \\
\text { IO }\end{array}$ \\
\hline Typ: & Paleta: & Producent: & Koniec produkcji: & Poprawki: & Wymiany: \\
\hline 4237 & 0074 & $\mathbf{P}$ & 2011-06-30 20:51:20 & - & - \\
\hline
\end{tabular}

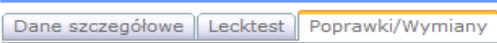

Poprawki

Data

\begin{tabular}{|l|l|l|l|l|} 
Poprawiający & REP & IAF & Stary & Nowy \\
status & status \\
\hline
\end{tabular}

Opis

2011-06-30 21:01:50 A

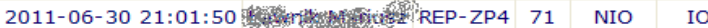

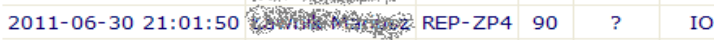

2011-06-30 21:01:50,

Wymiany

Data Poprawiajacy REP DMC

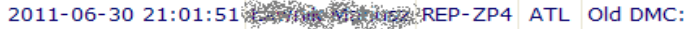

Fig. 4. Reporting available from the browser (www.amister.pl)

\section{CONCLUSIONS}


The analysis of the literature and research on available solutions were aimed at determining the usefulness and checking the effectiveness of knowledge and information management in manufacturing companies. Based on the research, the following phenomena were identified:

The elements of the comprehensive implementation of the amiMES system were defined:

- definition of problems presented by users,

- determining the scope of MES implementation on the basis of analyses carried out in the enterprise,

- defining process elements and designating responsibilities,

- network architecture analysis and modernization options,

- determining the possibilities of integration with external systems,

- separation of batches and production orders,

- division into storage and non-storage units,

- designating data collection points,

- data archiving,

- correlation of actual data with the standard,

- real-time visualization of key parameters,

- creating the right model,

- application tests,

- data collection from ERP,

- data connection between layers and correlation with MES,

- creating defined reports,

- execution of a test report before automatic synchronization with ERP,

- identification of data sources,

- data feeding of other systems in the plant.

The analysis was performed and the functionality of the tested system was confirmed:

- reporting of production in progress,

- linking intermediates with raw materials,

- real-time performance image of a particular area,

- determination of raw material productivity,

- minimization of machinery and equipment downtime,

- optimal use of production units,

- manager cockpit with a preview of the current work status.

The implementation of the presented systems and solutions for knowledge and information management in the enterprise will allow approaching the Overall Equipment Effectiveness (OEE) at the level of $85 \%$ (World Class Level). To achieve such results, we need to achieve the parameters at the level (Hamrol, 2015; World-Class OEE):

○ availability of $90.0 \%$,

- efficiency of $95.0 \%$,

○ quality of $99.9 \%$,

- $90 \% \times 95 \% \times 99.9 \%=85 \%$ OEE

- $60 \%$ - Average OEE for typical production plants

In order to determine further development possibilities of the described system, it would be necessary to conduct research in a dozen or so production plants where it was implemented and to compare the OEE results per year of each plant. If there are 
differences in the tests, an analysis and comparison of the operating environment of the systems should be performed to determine the reasons for the differences. On this basis, it is possible to define further modernization activities of the system, leading to the improvement of this solution and increasing the efficiency of factories.

\section{REFERENCES}

Biznes, 2007. Słownik pojęć ekonomicznych, Tom 10, PWN Publishing House, 195.

Bodył, T., 2016. Mniejsze produkty za te same pieniądze, Downsizing w modzie, wyborcza.biz, 8 września, [accessed on: 2016-12-22].

Brillman, J., 2002. Nowoczesne koncepcje i metody zarządzania, Warszawa, PWE.

Cary, L., Cooper, A.P., Campbell Quick J., 2015. Downsizing, Cambridge University Press.

Glosariusz ITIL wraz ze skrótami, 149, [accessed on: 2020-04-01] http. https://www.axelos.com/corporate/media/files/glossaries/itil_2011_glossary_pl-v1$0 . p d f$.

Glosariusz ITIL wraz ze skrótami, 86, [accessed on: 2020-04-01]. https://www.axelos.com/corporate/media/files/glossaries/itil_2011_glossary_pl-v10.pdf.

Graham, B.M., 1996. Keeping Score. Using the Right Metrics to drive World-Class Performance, New York: Productivity Press.

Grudzewski, W.M., Hejduk, I., 2018. Zarządzanie wiedzą w organizacjach, e-mentor, 21.05.2018.

Hamrol, A., 2015. Strategie i praktyki sprawnego działania, Wydawnictwo Naukowe PWN, ISBN 978-83-01-18137-6, Warszawa.

Horodecki, J., 2016. Male silniki się nie sprawdzają, https://www.autoswiat.pl/wiadomosci/aktualnosci/male-silniki-sie-nie-sprawdzaja-downsizingvolkswagen/p6xwk9t

https://www.amister.pl/menu-14-Przemysl_40-29.html

https://www.computerworld.pl/news/MES-krotki-przewodnik-po-systemachrealizacji-produkcji,412205.html, Date of publishing: 27.02.2019r.

Kisielnicki, J., 2004. Zarządzanie wiedzą we współczesnych organizacjach, Zarządzanie wiedzą w systemach informacyjnych, ed. by Abramowicz W., Nowicki A., Owoc M., Akademia Ekonomiczna Publishing House we Wrocławiu, Wrocław.

Marchwiński, C., Shook, J., Schroeder, A., 2010. Leksykon Lean. Ilustrowany słownik pojęć z zakresu Lean Management, Wrocław: Wydawnictwo Lean Enterprise Institute Polska, 2010, 10.

Mary, A., Junewick, 2002. LeanSpeak. The Productivity Business Improvement Dictionary, New York, Productivity Press, 2002, 139.

Matusiak, K.B. 2011. Innowacje i transfer technologii. Słownik pojęć, Polska Agencja Rozwoju Przedsiębiorczości, Warszawa, 299-301.

Mączyński, W., 2011. Wskaźniki OEE, MTBF i MTTR - czy to coś więcej niż wartości bezwzględne?, Utrzymanie Ruchu, 1.

MES, ERP dictionary, https://www.raport-erp.pl/slownik-erp/413-mes.html

Misiurek, B. 2015. Operator - najlepsza osoba do codziennego diagnozowania stanu maszyny, Służby Utrzymania Ruchu, Listopad 2015, [accessed on: 2017-12-14].

Misiurek, B., 2017. MTBF, MTTR i MTTF - jak i po co stosować te wskaźniki?, Służby Utrzymania Ruchu, 1/2017, January 2017. 
Misiurek, B., Maśluszczack, Z., 2015. Dlaczego w mojej firmie umarł TPM? Służby Utrzymania Ruchu, April 2015, 2017-12-14, https://lean.org.pl/dlaczego-w-mojejfirmie-umarl-tpm-histora-pewnego-wdrozenia/ Date of publishing:14.12.2017

Niemczyk, L., 2013. Rachunkowość finansowa aktywów kompetencyjnych i kapitału intelektualnego, nowy dział rachunkowości, , Paciolilnstitute Publishing House, Rzeszów.

Niepublikowane Materiały firmy Amister, https://www.amister.pl

Seiichi, N., 1988. Introduction to TPM: Total Productive Maintenance, 1 October 1988.

Stabryła, A., 2012. Podstawy organizacji i zarządzania. Podejścia i koncepcje badawcze, Universytet Ekonomiczny Publishing House in Krakow, Kraków.

Szabó, L., Csepregi, A., 2011. Competences Found Important for Knowledge Sharing: Investigation of Middle Managers Working at Medium- and Large-Sized Enterprises, IUP Journal of Knowledge Management, 9.

Wawak, S. 2014. Zarządzanie jakością Teoria i praktyka Wydanie II, One press Publishing House.

Willmott, P., McCarthy, D. 2001. TPM. A Route to World-Class Performance, Butterworth-Heinemann, 2001, 5.

Wojtkowiak, G., DOWNSIZING w przedsiębiorstwie stan, uwarunkowania, model, Wydawnictwo WUE - Uniwersytet Ekonomiczny w Poznaniu.

World-Class OEE, Set OEE Targets To Drive Improvement, https://www.oee.com/world-class-oee.html 